\title{
Epiboxidine and novel-related analogues: A convenient synthetic approach and estimation of their affinity at neuronal nicotinic acetylcholine receptor subtypes
}

\author{
Luca Rizzi $^{\mathrm{a}}$, Clelia Dallanoce ${ }^{\mathrm{a}, *}$, Carlo Matera $^{\mathrm{a}}$, Pietro Magrone ${ }^{\mathrm{a}}$, Luca Pucci ${ }^{\mathrm{b}}$, Cecilia Gotti ${ }^{\mathrm{b}}$, \\ Francesco Clementi ${ }^{\mathrm{b}}$, Marco De Amici ${ }^{\mathrm{a}}$ \\ a Istituto di Chimica Farmaceutica e Tossicologica "Pietro Pratesi", Università degli Studi di Milano, Via Mangiagalli 25, 20133 Milano, Italy \\ ${ }^{\mathrm{b}}$ CNR, Istituto di Neuroscienze, Farmacologia Cellulare e Molecolare e Dipartimento Farmacologia, Chemioterapia e Tossicologia Medica, Università degli Studi di Milano, \\ Via Vanvitelli 32, 20129 Milano, Italy
}

\section{A R T I C L E I N F O}

\section{Article history:}

Received 18 June 2008

Revised 3 July 2008

Accepted 4 July 2008

Available online 10 July 2008

\section{Keywords:}

Neuronal nicotinic acetylcholine receptors Epiboxidine

Nicotinic ligands

Binding affinity

\begin{abstract}
A B S T R A C T
Racemic exo-epiboxidine 3, endo-epiboxidine $\mathbf{6}$, and the two unsaturated epiboxidine-related derivatives $\mathbf{7}$ and $\mathbf{8}$ were efficiently prepared taking advantage of a palladium-catalyzed Stille coupling as the key step in the reaction sequence. The target compounds were assayed for their binding affinity at neuronal $\alpha 4 \beta 2$ and $\alpha 7$ nicotinic acetylcholine receptors. Epiboxidine 3 behaved as a high affinity $\alpha 4 \beta 2$ ligand $\left(K_{\mathrm{i}}=0.4 \mathrm{nM}\right)$ and, interestingly, evidenced a relevant affinity also for the $\alpha 7$ subtype $\left(K_{\mathrm{i}}=6 \mathrm{nM}\right)$. Derivative $\mathbf{7}$, the closest analogue of $\mathbf{3}$ in this group, bound with lower affinity at both receptor subtypes $\left(K_{\mathrm{i}}=50 \mathrm{nM}\right.$ for $\alpha 4 \beta 2$ and $K_{\mathrm{i}}=1.6 \mu \mathrm{M}$ for $\alpha 7$ ) evidenced a gain in the $\alpha 4 \beta 2$ versus $\alpha 7$ selectivity when compared with the model compound.
\end{abstract}

(ㄷ) 2008 Elsevier Ltd. All rights reserved.
Neuronal nicotinic acetylcholine receptors (nAChRs) make up a family of pentameric ligand-gated ion channels, which are formed by combinations of alpha and beta subunits ${ }^{1,2}$ or exist as homopentamers, in the cases of $\alpha 7, \alpha 8$, and $\alpha 9$ receptors, which are inhibited by $\alpha$-bungarotoxin. ${ }^{3}$ To date, nine $\alpha(\alpha 2-\alpha 10)$ and three $\beta$ ( $\beta 2-\beta 4)$ isoforms have been characterized, though only a relatively small subset of combinations generates functionally and physiologically relevant channels. ${ }^{4}$ Nicotinic receptors are widely distributed in the brain, where they primarily modulate the release of other neurotransmitters and, to a lesser extent, mediate synaptic transmission. ${ }^{5}$ Neuronal nAChRs, selectively activated by $(S)$-nicotine 1 (Fig. 1), are involved in various processes such as cognition, learning and memory, cerebral blood flow and metabolism, as well as an array of pathological conditions such as Alzheimer's and Parkinson's diseases, mild cognitive impairment (MCI), schizophrenia, epilepsy, Tourette's syndrome, anxiety, depression, attention-deficit hyperactivity disorder (ADHD), and nicotine addiction. ${ }^{1,2,6,7}$

The heteromeric $\alpha 4 \beta 2$ receptors, the most abundant subtype in the mammalian CNS, and the homomeric $\alpha 7$ channels are privileged biological targets in the search for selective $\mathrm{nAChR}$ ligands with therapeutic potential. ${ }^{2,8}$ As far as the number of nicotinic agonists isolated from natural sources is taken into consideration, ${ }^{9}$

\footnotetext{
* Corresponding author. Tel.: +39 02 50319327; fax: +39 0250319326 .

E-mail address: clelia.dallanoce@unimi.it (C. Dallanoce).
}

(-)-epibatidine $\mathbf{2}$ (Fig. 1), a highly toxic alkaloid identified in the skin of the Ecuadorian frog Epipedobates tricolor, ${ }^{10}$ has inspired a huge amount of research aimed at designing subtype selective nicotinic agonists. ${ }^{1,2,9,11,12}$ Although the pharmacological effects of (-)-2 are mediated by a variety of nAChRs, ${ }^{13}$ which preclude any therapeutic potential for epibatidine, the analgesic potency, roughly 100 times higher than that of morphine and 30 times higher than that of nicotine, has been attributed to its high affinity for the $\alpha 4 \beta 2$ subtype. Worth mentioning, (-)-2 and (+)-2 are characterized by similar affinities for nAChRs and almost identical $\mathrm{ED}_{50}$ values in the mouse tail-flick antinociception assay. ${ }^{13 d, 14,15}$

Among the synthetic epibatidine-related compounds, ( \pm )-epiboxidine 3 (Fig. 1), in which the 3-methylisoxazolyl moiety has replaced the chloropyridinyl ring of the parent derivative, behaved as a potent $\alpha 4 \beta 2$ nicotinic receptor agonist, 10 -fold less potent than epibatidine as antinociceptive agent but about 20 -fold less toxic. ${ }^{16}$ The presence of the 3-methylisoxazole ring was similarly effective in the structure of (S)-ABT-418 4 (Fig. 1), a nicotine-related $\alpha 4 \beta 2$ selective full agonist, which entered Phase I for the treatment of cognitive dysfunction and was later on discontinued. ${ }^{2,7,17}$ A further relevant example of structural analogue of epibatidine is the unsaturated derivative $( \pm)$-UB-165 5, containing the 9-azabicyclo[4.2.1]nonene skeleton, a high affinity nicotinic partial agonist which allowed to clarify the involvement of the $\alpha 4 \beta 2$ subtype in modulating dopamine release from rat striatal synaptosomes. ${ }^{18,19}$ 


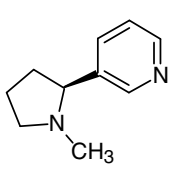

1 (S)-Nicotine<smiles>Clc1ccc([C@@H]2C[C@@H]3CC[C@H]2N3)cn1</smiles>

2 (-)-Epibatidine<smiles>Cc1cc(C2CC3CCN2C3)on1</smiles>

3 ( \pm )-Epiboxidine

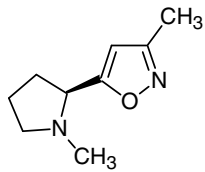

4 (S)-ABT-418<smiles>Clc1ccc(C2=CCCC3CCC2N3)cn1</smiles>

$5( \pm)-U B-165$

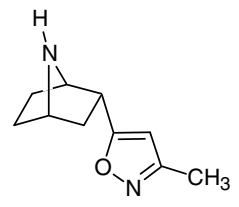

6 ( \pm )-endo-Epiboxidine

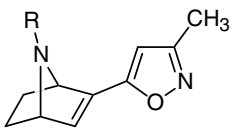

$( \pm)-7: \mathrm{R}=\mathrm{H}$

$( \pm)-8: \mathrm{R}=\mathrm{CH}_{3}$

Figure 1. Structures of model and target compounds in this study.

In the present study, we aimed at further investigating epiboxidine, that is, at $\alpha 7$ nAChRs, a subtype on which, to the best of our knowledge, it was never assayed. To this end, we thought about a flexible synthesis of $( \pm)-3$ allowing also the preparation of unsaturated structurally related derivatives. Accordingly, we describe a novel synthetic route to epiboxidine 3 (exo-isomer), its epimer endo-epiboxidine 6, and the two unprecedented dehydro-analogues of epiboxidine $\mathbf{7}$ and $\mathbf{8}$. The target chiral compounds, whose structures are reported in Figure 1, were prepared and tested as racemates.

As illustrated in the upper part of Scheme 1, the known preparations of 3 took advantage of the reaction of 7-azabicyclo[2.2.1]heptane-2,7-dicarboxylic acid diesters 9a and 9b with the dianion of acetone oxime, followed by acidic treatment of intermediates 10a and 10b. ${ }^{16,20}$ As an alternative approach, we planned to make use of a Stille palladium-catalyzed cross-coupling reaction, ${ }^{21}$ which involved the coupling of enoltriflate 11 with 3methyl-5-tributylstannylisoxazole $\mathbf{1 2}$, as depicted in the lower part of Scheme 1.

Initially, we made use of a known procedure to prepare 7-tertbutoxycarbonyl-7-azabicyclo[2.2.1]heptan-2-one 16, a key intermediate in one of the syntheses of $( \pm)$-epibatidine. ${ }^{22}$ The first step of the sequence, a [4+2] cycloaddition of $N$-Boc-pyrrole 13, used in large excess, to methyl 3-bromopropiolate 14, was performed under microwave heating (Scheme 2). ${ }^{23}$ These experimental conditions allowed reduction of the reaction time (from 30 to $1.5 \mathrm{~h}$ ) and improvement of the yield of the Diels-Alder adduct $\mathbf{1 5}$ (from $60 \%$ to $85 \%$ ). Subsequently, we prepared the known trifluorometh-

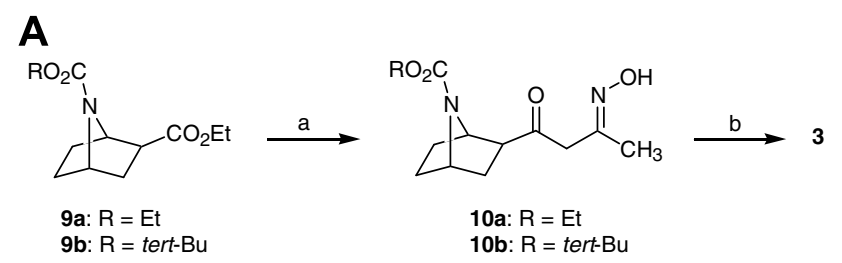

(a) Acetone oxime, $n \mathrm{BuLi}$; (b) conc. $\mathrm{HCl}, 80^{\circ} \mathrm{C}$
B 3

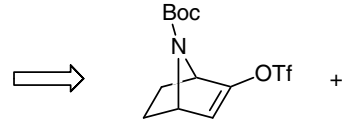

11

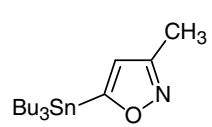

12
Scheme 1. (A) Key steps of the known synthetic strategy to epiboxidine 3. (B) Retrosynthesis of 3 based on a Stille coupling reaction.

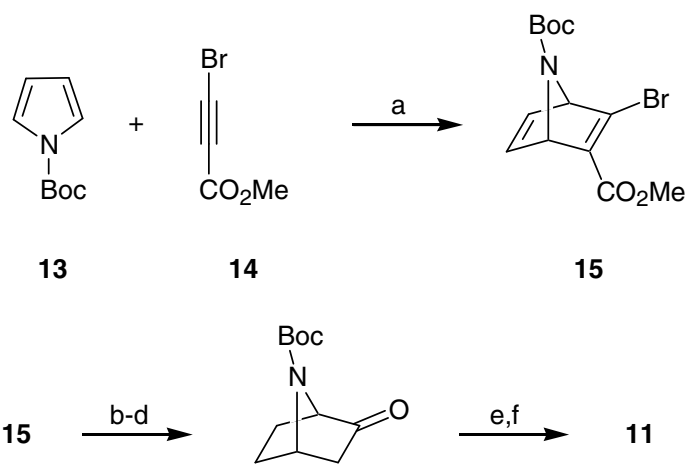

16

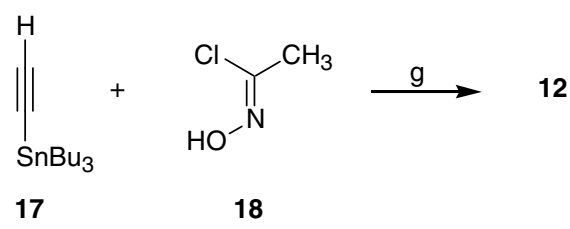

Scheme 2. (a) $\mathrm{MW}, 90^{\circ} \mathrm{C}, 1.5 \mathrm{~h}$, neat; (b)-(d) see Ref. 22; (e) (iPr) ${ }_{2} \mathrm{NH} / n$-BuLi, $-78{ }^{\circ} \mathrm{C}$; (f) $\mathrm{N}$-(5-chloro-2-pyridyl)bis(trifluoromethanesulfonimide), $-78^{\circ} \mathrm{C}$ to $\mathrm{rt}$; (g) $\mathrm{NEt}_{3} / \mathrm{THF}, \mathrm{rt}, 5 \mathrm{~h}$.

anesulfonate $\mathbf{1 1}^{24}$ in $62 \%$ isolated yield by treatment of ketone $\mathbf{1 6}$ with LDA in THF at $-78{ }^{\circ} \mathrm{C}^{25}$ followed by reaction with $\mathrm{N}$-(5chloro-2-pyridyl)bis(trifluoromethanesulfonimide) ${ }^{26}$ (Scheme 2). 3-Methyl-5-tributylstannylisoxazole $\mathbf{1 2}$ was obtained through the previously described 1,3-dipolar cycloaddition of tributylethynyltin 17 to acetonitrile oxide. ${ }^{27}$ As a modification of the known procedure, we chose to isolate the stable precursor of the 1,3-dipole, that is, the acetohydroximoyl chloride $\mathbf{1 8}$, which in turn was synthesized by reacting acetaldoxime with benzyltrimethylammonium tetrachloroiodate (BTMA $\left.\mathrm{ICl}_{4}\right)^{28,29}$ In this way, the target tributylstannylisoxazole $\mathbf{1 2}$ was prepared in acceptable yields (45-50\%).

The Stille cross-coupling reaction of triflate $\mathbf{1 1}$ to isoxazole $\mathbf{1 2}$, performed in the presence of the Tris(dibenzylideneacetone)dipalladium(0)-chloroform adduct, triphenylphosphine, and anhydrous $\mathrm{ZnCl}_{2}$, produced the 7-azabicyclo[2.2.1] hept-2-ene derivative 19 in $90 \%$ yield (Scheme 3 ). ${ }^{30}$ Removal of the $\mathrm{N}$-Boc protection of 19 with a $4 \mathrm{~N}$ solution of $\mathrm{HCl}$ in dioxane afforded the secondary amine 7 , which was converted into the corresponding $N$-methyl derivative $\mathbf{8}$ by a standard reaction with formaldehyde followed by reduction 


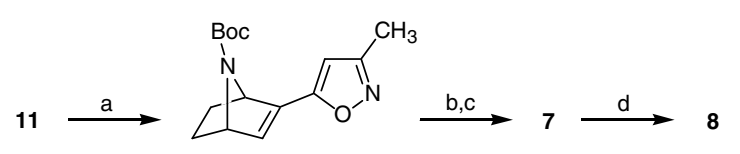

19
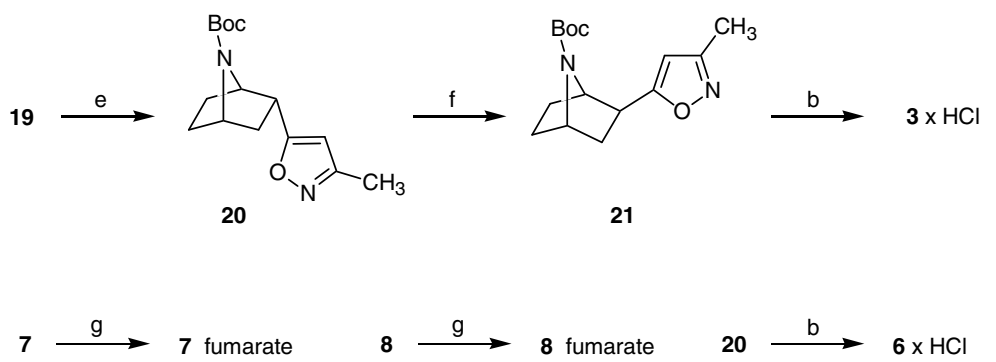

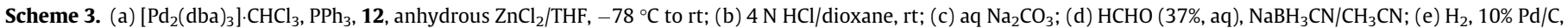
$\mathrm{CH}_{3} \mathrm{OH}$; (f) tert-BuOK/tert-BuOH, reflux, $16 \mathrm{~h}$, flash chromatography; (g) $\mathrm{C}_{4} \mathrm{H}_{4} \mathrm{O}_{4}, \mathrm{CH}_{3} \mathrm{OH}$.

of the intermediate aldimine with sodium cyanoborohydride. Next, hydrogenation of the carbon-carbon double bond of 19 over $10 \%$ $\mathrm{Pd} / \mathrm{C}$ allowed the isolation of $\mathrm{N}$-Boc-endo-epiboxidine $\mathbf{2 0}$ as the sole isomer in $87 \%$ yield. ${ }^{31}$ Epimerization of $\mathbf{2 0}$ using potassium tert-butoxide in refluxing tert-butyl alcohol ${ }^{22,31}$ provided the desired $\mathrm{N}$-Boc-exo-epiboxidine $\mathbf{2 1}$ in $82 \%$ yield. The two epiboxidine epimers endo-6 and exo-3 were isolated as crystalline hydrochlorides following acidic treatment of the corresponding $\mathrm{N}$-Boc protected endo-20 and exo-21 precursors, respectively (Scheme 3). Specifically, the physical and spectroscopic features of $\mathbf{3}$ hydrochloride $^{16,32}$ matched those of the known compound, now commercially available from Sigma. Since the hydrochlorides of $\mathbf{7}$ and 8 were amorphous salts, the free bases were reacted with a solution of fumaric acid in methanol to give rise to the corresponding 1:1 fumarates (Scheme 3).

The target racemic compounds $\mathbf{3 , 6}, \mathbf{7}$, and $\mathbf{8}$ were assayed for binding affinity at rat $\alpha 4 \beta 2$ and $\alpha 7$ nAChR subtypes, using $\left[{ }^{3} \mathrm{H}\right]$ epibatidine and $\left[{ }^{125} \mathrm{I}\right] \alpha$-bungarotoxin as radioligands, respectively. The $K_{\mathrm{i}}$ values, calculated from the competition curves of three separate experiments by means of the LIGAND program, ${ }^{33}$ are collected in Table 1 . The corresponding values reported for $( \pm)$-epibatidine 2, (S)-4 (ABT-418), and ( \pm )-5 (UB-165) have been included for comparison.

The data found for epiboxidine $\mathbf{3}$ confirm its very high affinity $\left(K_{\mathrm{i}}=0.4 \mathrm{nM}\right)$ for $\alpha 4 \beta 2$ nAChRs, which complements the results known from the literature $\left(K_{\mathrm{i}}=0.6 \mathrm{nM},{ }^{16} K_{\mathrm{i}}=1.33 \mathrm{nM},{ }^{34}\right.$ and $\left.K_{\mathrm{i}}=0.46 \mathrm{nM}^{35}\right)$. A comparison between 2 and 3 evidences about a 10 -fold higher affinity of 2 at the $\alpha 4 \beta 2$ receptors ( $K_{\mathrm{i}}$ values

\section{Table 1}

Affinity of ( \pm )-epibatidine 2, ABT-418 (S)-4, UB-165 5, and derivatives 3, 6, 7, and 8 for native $\alpha 4 \beta 2$ and $\alpha 7 \mathrm{nAChR}$ subtypes present in rat cortical membranes, labeled by $\left[{ }^{3} \mathrm{H}\right]$ epibatidine and $\left[{ }^{125} \mathrm{I}\right] \alpha$-bungarotoxin

\begin{tabular}{lll}
\hline Entry & $\alpha 4 \beta 2\left[{ }^{3} \mathrm{H}\right]-$ Epi $K_{\mathrm{i}}(\mathrm{nM})$ & $\alpha 7\left[{ }^{125} \mathrm{I}\right] \alpha-\operatorname{BgTx} K_{\mathrm{i}}(\mathrm{nM})$ \\
\hline$( \pm)-2$ & $0.035^{\mathrm{a}}$ & $10.2^{\mathrm{a}}$ \\
$(S)-4$ & $20.0^{\mathrm{b}}$ & $1200^{\mathrm{b}}$ \\
$( \pm)-5$ & $0.27^{\mathrm{c}}$ & $2790^{\mathrm{c}}$ \\
$( \pm)-3$ & $0.40(57)$ & $6.0(47)$ \\
$( \pm)-6$ & $70(49)$ & $230(51)$ \\
$( \pm)-7$ & $50(23)$ & $1600(63)$ \\
$( \pm)-8$ & $514(34)$ & $394(44)$ \\
\hline
\end{tabular}

\footnotetext{
The numbers in brackets refer to the \% coefficient of variation.

a Ref. $40,\left[{ }^{3} \mathrm{H}\right]$ nicotine was used as radioligand for $\alpha 4 \beta 2$ receptors.

b Ref. 36.

c Ref. $19,\left[{ }^{3} \mathrm{H}\right]$ nicotine was used as radioligand for $\alpha 4 \beta 2$ receptors.
}

$0.035 \mathrm{nM}$ for 2 and $0.4 \mathrm{nM}$ for 3 ) combined with a lower affinity at $\alpha 7$ receptors ( $K_{\mathrm{i}}$ values $10.2 \mathrm{nM}$ for 2 and $6.0 \mathrm{nM}$ for 3 ). As a consequence, a meaningful difference in the $\alpha 4 \beta 2$ versus $\alpha 7$ selectivity ratio (290 for $\mathbf{2}$ and 15 for $\mathbf{3}$ ) characterizes the two structural analogues. An intermediate selectivity has been recently found for the 3-methylisoxazolyl nicotine-related derivative ABT-418 (S)-4. ${ }^{36}$ If the data on epiboxidine $\mathbf{3}$ are taken into account, the binding affinity of $(S)-\mathbf{4}$ at the $\alpha 7$ subtype $\left(K_{\mathrm{i}}=1.2 \mu \mathrm{M}\right)$ is negatively affected more than at the $\alpha 4 \beta 2$ receptors $\left(K_{\mathrm{i}}=20 \mathrm{nM}\right)$, thus bringing about an $\alpha 4 \beta 2$ versus $\alpha 7$ selectivity ratio of 60 .

In terms of binding affinity, UB-165 5, the semirigid homologue of epibatidine, showed a considerable degree of discrimination between the two neuronal nAChRs under study, the $\alpha 4 \beta 2$ versus $\alpha 7$ selectivity being higher than 10,000 , due to a partially conserved affinity at the $\alpha 4 \beta 2$ subtype $\left(K_{\mathrm{i}}=0.27 \mathrm{nM}\right)$ coupled with a sizeable loss of affinity at the $\alpha 7$ subtype $\left(K_{\mathrm{i}}=2.8 \mu \mathrm{M}\right) .{ }^{19}$ Also derivative 7 , the unsaturated analogue of epiboxidine, was characterized by a marked drop of the affinity at the $\alpha 7$ subtype $\left(K_{\mathrm{i}}=1.6 \mu \mathrm{M}\right)$ when compared to the parent compound. However, the presence of the double bond in $\mathbf{7}$ caused a reduction of the affinity even at the $\alpha 4 \beta 2$ subtype $\left(K_{\mathrm{i}}=50 \mathrm{nM}\right)$. As a consequence, only a minor improvement of the $\alpha 4 \beta 2$ versus $\alpha 7$ selectivity (from 15 for 3 to 32 for 7) was attained. Worth noting, in terms of affinity profile at the two studied nAChRs, the results on racemic $\mathbf{7}$ are quite comparable with those obtained in the same experimental conditions for the pure isomer ABT-418. ${ }^{36}$

At variance with the secondary amine 7 , the corresponding $\mathrm{N}$ methyl derivative $\mathbf{8}$ was characterized as a low affinity unselective nicotinic ligand $\left(K_{\mathrm{i}}=0.51 \mu \mathrm{M}\right.$ at $\alpha 4 \beta 2$ and $0.39 \mu \mathrm{M}$ at $\left.\alpha 7\right)$. A similar lack of selectivity was evidenced by endo-epiboxidine $\mathbf{6}$, which, in comparison with the exo-isomer $\mathbf{3}$, retained a non negligible affinity at both $\alpha 4 \beta 2\left(K_{\mathrm{i}}=70 \mathrm{nM}\right)$ and $\alpha 7\left(K_{\mathrm{i}}=0.23 \mu \mathrm{M}\right)$ nAChR subtypes. The same trend was reported at the $\alpha 4 \beta 2$ subtype for $( \pm)$-endo-epibatidine, ${ }^{13 d}$ which exhibited a drastic reduction of affinity when compared to $( \pm)$-exo-epibatidine $\left(K_{\mathrm{i}}\right.$ values 7.6 and $0.035 \mathrm{nM}$, respectively), ${ }^{37}$ coupled with the loss of the antinociceptive activity in the tail-flick test. ${ }^{14}$

In summary, we utilized a Pd-catalyzed Stille coupling reaction as the pivotal step to prepare the two epiboxidine epimers and two unsaturated epiboxidine-related analogues. We assessed the four compounds for binding affinity at $\alpha 4 \beta 2$ and $\alpha 7$, the two major neuronal nicotinic receptor subtypes. Noteworthy, $( \pm)$-exo-epiboxidine 3 displayed a very high affinity at both nAChRs, whereas in its analogue $\mathbf{7}$ the presence of the double bond caused a loss of affinity at both subtypes together with a higher degree of $\alpha 4 \beta 2$ versus $\alpha 7$ 
selectivity. We will broaden the study on this set of compounds by enriching the number of unsaturated analogues and preparing the individual isomers of $( \pm)-3$ and $( \pm)-7$. The pharmacological results will be further analyzed in the light of recently developed molecular models for the two investigated receptor subtypes. ${ }^{38,39}$

\section{Acknowledgments}

This research was financially supported by the Italian FIRB Grant \# RBNE03FH5Y_002, the PRIN Grant \# 2005054943 (F.C., C.G., and M.D.A.), and the Fondazione Cariplo Grant \# 2006/0882 (F.C. and M.D.A.).

\section{References}

1. Jensen, A. A.; Frølund, B.; Liljefors, T.; Krogsgaard-Larsen, P. J. Med. Chem. 2005, $48,4705$.

2. Romanelli, M. N.; Gratteri, P.; Guandalini, L.; Martini, E.; Bonaccini, C.; Gualtieri, F. ChemMedChem 2007, 2, 746.

3. Séguéla, P.; Wadiche, J.; Dineley-Miller, K.; Dani, J. A.; Patrick, J. W. J. Neurosci. 1993, 13, 596.

4. Weiland, S.; Bertrand, D.; Leonard, S. Behav. Brain Res. 2000, 113, 43.

5. Dajas-Bailador, F. Wonnacott, S. Trends Pharmacol. Sci. 2004, 25, 317.

6. Gotti, C.; Clementi, F. Progr. Neurobiol. 2004, 74, 363.

7. Lloyd, G. K.; Williams, M. J. Pharmacol. Exp. Ther. 2000, 292, 461.

8. Mazurov, A.; Hauser, T.; Miller, C. H. Curr. Med. Chem. 2006, 13, 1567.

9. Daly, J. W. Cell. Mol. Neurobiol. 2005, 25, 513.

10. Spande, T. F.; Garraffo, H. M.; Edwards, M. W.; Yeh, H. J. C.; Pannell, L.; Daly, J. W. J. Am. Chem. Soc. 1992, 114, 3475.

11. Romanelli, M. N.; Gualtieri, F. Med. Chem. Rev. 2003, 23, 393.

12. White, R.; Malpass, J. R.; Handa, S.; Baker, S. R.; Broad, L. M.; Folly, L.; Mogg, A Bioorg. Med. Chem. Lett. 2006, 16, 5493.

13. (a) Sullivan, J. P.; Bannon, A. W. CNS Drug Rev. 1996, 2, 21; (b) Gerzanich, V.; Peng, X.; Wang, F.; Wells, G.; Anand, R.; Fletcher, S.; Lindstrom, J. Mol. Pharmacol. 1995, 48, 774; (c) Sullivan, J. P.; Decker, M. W.; Brioni, J. D.; Donnelly-Roberts, D. L.; Anderson, D. A.; Bannon Kang, A. W. C. H.; Adams, P.; Piattoni-Kaplan, M.; Buckley, M. J.; Gopalakrishnan, M.; Williams, M.; Arneric S. P. J. Pharmacol. Exp. Ther. 1994, 271, 624; (d) Carroll, F. I. Bioorg. Med. Chem. Lett. 2004, 14, 1889. (and reference cited therein).

14. Li, T.; Qian, C.; Eckman, J.; Huang, D. F.; Shen, T. Y. Bioorg. Med. Chem. Lett. 1993, 3, 2759 .

15. Damaj, M. I.; Glassco, W.; Dukat, M.; May, E. L.; Glennon, R. A.; Martin, B. R. Drug Dev. Res. 1996, 38, 177.

16. Badio, B.; Garraffo, H. M.; Plummer, C. V.; Padgett, W. L.; Daly, J. W. Eur. J. Pharmacol. 1997, 321, 189.

17. Garvey, D. S.; Wasicak, J. T.; Decker, M. W.; Brioni, J. D.; Buckley, M. J.; Sullivan, J. P.; Carrera, G. M.; Holladay, M. W.; Arneric, S. P.; Williams, M. J. Med. Chem. 1994, 37, 1055.

18. Wright, E.; Gallagher, T.; Sharples, C. G. V.; Wonnacott, S. Bioorg. Med. Chem. Lett. 1997, 7, 2867.

19. Sharples, C. G. V.; Kaiser, S.; Soliakov, L.; Marks, M. J.; Collins, A. C.; Washburn, M.; Wright, E.; Spencer, J. A.; Gallagher, T.; Whiteaker, P.; Wonnacott, S. J. Neurosci. 2000, 20, 2783.

20. Pandey, G.; Sahoo, A. K.; Gadre, S. R.; Bagul, T. D.; Phalgune, U. D. J. Org. Chem. 1999, 64, 4990.

21. For recent reviews on the Stille reaction and the related Pd-catalyzed crosscoupling reactions, see: (a) Farina, V.; Krishnamurphy, V.; Scott, V. J. Org. React. 1997, 50, 1; (b) Espinet, P.; Echavarren, A. M. Angew. Chem., Int. Ed. 2004, 43,
4704; (c) Nicolaou, K. C.; Bulger, P. G.; Sarlah, D. Angew. Chem., Int. Ed. 2005, 44 4442; (d) Yin, L; Liebscher, J. Chem. Rev 2007, 107, 133.

22. Zhang, C.; Trudell, M. L. J. Org. Chem. 1996, 61, 7189.

23. For recent reviews on the use of microwaves in organic synthesis, see (a) Kappe, C. O. Angew. Chem., Int. Ed. 2004, 43, 6250; (b) Kappe, C. O.; Dallinger, D. Nat. Rev. Drug Discov. 2006, 5, 51.

24. Carroll, F. I.; Liang, F.; Navarro, H. A.; Brieaddy, L. E.; Abraham, P.; Damaj, M. I.; Martin, B. R. J. Med. Chem. 2001, 44, 2229.

25. Tessier, P. E.; Nguyen, N.; Clay, M.; Fallis, A. G. Org. Lett. 2005, 7, 767.

26. Choi, Y.; White, J. D. J. Org. Chem. 2004, 69, 3758.

27. Lee, J. S.; Cho, Y. S.; Chang, M. H.; Koh, H. Y.; Chung, B. Y.; Pae, A. N. Bioorg. Med. Chem. Lett. 2003, 13, 4117. (and references cited therein).

28. Kanemasa, S.; Matsuda, H.; Kamimura, A.; Kakinami, T. Tetrahedron 2000, 56 1057.

29. Dallanoce, C.; Rizzi, L.; Magrone, P.; Bazza, P.; Grazioso, G.; Riganti, L.; Gotti, C.; Clementi, F.; Frydenvang, K.; De Amici, M. Chem. Biodivers., in press.

30. 2-(3-Methylisoxazol-5-yl)-7-azabicyclo[2.2.1] hept-2-ene-7-carboxylic acid tert-butyl ester (19). To a magnetically stirred solution of enoltriflate $\mathbf{1 1}$ $(1.10 \mathrm{~g}, 3.20 \mathrm{mmol})$ in anhydrous THF $(15 \mathrm{~mL})$ kept at $-78^{\circ} \mathrm{C}$ under argon were sequentially added $\left[\mathrm{Pd}_{2}(\mathrm{dba})_{3}\right] \cdot \mathrm{CHCl}_{3} \quad(275 \mathrm{mg}, \quad 0.26 \mathrm{mmol})$ triphenylphosphine $(68 \mathrm{mg}, 0.26 \mathrm{mmol})$, then a solution of isoxazole 12 $(1.70 \mathrm{~g}, 4.57 \mathrm{mmol})$ in THF $(10 \mathrm{~mL})$ and anhydrous $\mathrm{ZnCl}_{2} \quad(437 \mathrm{mg}$, $3.21 \mathrm{mmol}$ ). The mixture was quickly warmed at $\mathrm{rt}$ and stirred for about 3 days under argon until disappearance of the starting material (TLC, 10\% ethyl acetate/petroleum ether). After addition of water $(20 \mathrm{~mL})$, the crude reaction was repeatedly extracted with ethyl acetate $(4 \times 20 \mathrm{~mL})$. The combined organic extracts were treated with brine $(20 \mathrm{~mL})$, then dried over anhydrous sodium sulfate. After concentration under reduced pressure, the residue was purified by silica gel column chromatography ( $10 \%$ ethyl acetate/petroleum ether) to afford $797 \mathrm{mg}$ (90\% yield) of the required isoxazolyl derivative 19. Colorless prisms (from $n$-hexane), $m p 84-85^{\circ} \mathrm{C}$. $R_{f}=0.50$ (20\% ethyl acetate/petroleum ether). ${ }^{1} \mathrm{H}$ NMR $\left(300 \mathrm{MHz}, \mathrm{CDCl}_{3}\right): \delta$ $1.24(\mathrm{~m}, 2 \mathrm{H}), 1.41(\mathrm{~s}, 9 \mathrm{H}), 2.00(\mathrm{~m}, 2 \mathrm{H}), 2.30(\mathrm{~s}, 3 \mathrm{H}), 4.82(\mathrm{br} \mathrm{s}, 1 \mathrm{H}), 4.94(\mathrm{br}$ s, $1 \mathrm{H}), 6.10(\mathrm{~s}, 1 \mathrm{H}), 6.68(\mathrm{~s}, 1 \mathrm{H}) .{ }^{13} \mathrm{C}$ NMR $\left(75 \mathrm{MHz}, \mathrm{CDCl}_{3}\right): \delta 11.65,24.49$, $25.43,28.41,61.06,80.65,102.20,133.32,135.08,155.22,160.28,163.95$ $\mathrm{C}_{15} \mathrm{H}_{20} \mathrm{~N}_{2} \mathrm{O}_{3}$ (276.33): calcd. C 65.20, H 7.30, N 10.14; found C 65.37, H 7.22, $\mathrm{N} 10.02$.

31. Catalytic hydrogenation of the corresponding olefin for the synthesis of $( \pm)$ epibatidine afforded the endo/exo $N$-Boc-epibatidines in a 4:1 ratio, as reported by Fletcher, S. R.; Baker, R.; Chambers, M. S. Herbert, R. H.; Hobbs, S. C.; Thomas, S. R.; Verrier, H. M.; Watt, A. P.; Ball, G. R. J. Org. Chem. 1994, 59, 1771

32. ( \pm -exo-2-(3-Methylisoxazol-5-yl)-7-azabicyclo[2.2.1] heptane hydrochloride (3. $\mathrm{HCl}$ ). Pale yellow prisms (anhydrous ether washings), mp $200-205^{\circ} \mathrm{C}$ (dec). ${ }^{1} \mathrm{H}$ NMR $\left(300 \mathrm{MHz}, \mathrm{D}_{2} \mathrm{O}\right): \delta 2.04(\mathrm{~m}, 5 \mathrm{H}), 2.28(\mathrm{~s}, 3 \mathrm{H}), 2.40(\mathrm{~m}, 1 \mathrm{H}), 3.57$ (dd, $1 \mathrm{H}, J=5.5$ and $9.2 \mathrm{~Hz}), 4.41(\mathrm{br} \mathrm{s}, 1 \mathrm{H}), 4.53(\mathrm{~d}, 1 \mathrm{H}, J=2.8 \mathrm{~Hz}), 6.26(\mathrm{~s}, 1 \mathrm{H})$ ${ }^{13} \mathrm{C}$ NMR $\left(75 \mathrm{MHz}, \mathrm{D}_{2} \mathrm{O}\right): \delta 10.54,25.61,26.54,33.84,37.86,58.97,62.43$, 103.02, 161.91, 171.90. $\mathrm{C}_{10} \mathrm{H}_{15} \mathrm{ClN}_{2} \mathrm{O}$ (214.69): calcd. C 55.94, H 7.04, $\mathrm{Cl} 16.51$, N 13.05; found C 56.12, H 6.91, Cl 16.77, N 13.15.

33. Munson, P. J.; Rodbard, D. Anal. Biochem. 1980, 107, 220.

34. Singh, S.; Avor, K. S.; Pouw, B.; Seale, T. W.; Basmadjian, G. P. Chem. Pharm. Bull. 1999, 47, 1501.

35. Fitch, R. W.; Pei, X.-F. ; Kaneko, Y.; Gupta, T.; Shi, D.; Federova, I.; Daly, J. W. Bioorg. Med. Chem. 2004, 12, 179.

36. Pallavicini, M.; Moroni, B.; Bolchi, C.; Clementi, F.; Fumagalli, L.; Gotti, C. Vailati, S.; Valoti, E.; Villa, L. Bioorg. Med. Chem. Lett. 2004, 14, 5827.

37. Dart, M. J.; Wasicak, J. T.; Ryther, K. B.; Schrimpf, M. R.; Kim, K. H.; Anderson, D. J.; Sullivan, J. P.; Meyer, M. D. Pharm. Acta Helv. 2000, 74, 115.

38. Huang, X.; Zheng, F.; Chen, X.; Crooks, P. A.; Dwoskin, L. P.; Zhan, C. G. J. Med. 2006, 49,7661

39. Grazioso, G.; Cavalli, A.; De Amici, M.; Recanatini, M.; De Micheli, C. J. Comput Chem., in press (10.1002/jcc.21019).

40. Zhang, N.; Tomizawa, M.; Casida, J. E. Bioorg. Med. Chem. Lett. 2003, 13, 525 